ERIC R. BOOT*

\title{
THE FEASIBILITY OF A PUBLIC INTEREST DEFENSE FOR WHISTLEBLOWING
}

(Accepted 13 May 2019)

\begin{abstract}
It is commonly stated, by both whistleblower protection laws and political philosophers, that a breach of state secrecy by disclosing classified documents is justified if it serves the public interest. The problem with this defense of justified whistleblowing, however, is that the operative term - the public interest is all too often left unclarified. This is problematic, because it leaves potential whistleblowers without sufficient certainty that their disclosures will be covered by the defense, leading many to err on the side of caution and remain silent, depriving the public of much-needed information. Failing an agreed upon definition of the public interest or a process to determine it, judges' applications of the public interest in whistleblowing cases have been criticized for demonstrating 'judicial idiosyncrasy'. The present paper, therefore, sets out to (1) provide some clarity concerning the concept of the public interest, and (2) to ascertain the extent to which a public interest defense for whistleblowing is feasible and desirable.
\end{abstract}

\section{INTRODUCING THE PROBLEM}

Contemporary liberal democracies recognize the importance of citizens having access to government information. Transparency is of fundamental importance for an informed public debate as well as for democratic accountability, which is why many countries have freedom of information laws. Nonetheless, few support Julian Assange's call for complete transparency and his rejection of legitimate secrets. Even NGOs promoting transparency such as Transparency International are prepared to allow for exceptions when national security and official secrets are involved. ${ }^{1}$ At times, it is necessary and

\footnotetext{
${ }^{1}$ Mark Worth, Whistleblowing in Europe: Legal Protections for Whistleblowers in the EU. (Transparency International, 2013), p. 89. Available at: https://www.transparency.org/whatwedo/publication/ whistleblowing_in_europe_legal_protections_for_whistleblowers_in_the_eu.
} 
legitimate for governments to keep certain information secret. Accordingly, citizens' access to information may be limited. For example, in the United States the 'Freedom of Information Act (FOIA) explicitly exempts properly classified information from disclosure, protecting any document properly classified from release in response to a public request'. ${ }^{2}$ Despite the prohibition on disclosing classified documents, however, government secrets are on a relatively regular basis made public by whistleblowers. Such unauthorized disclosures will be the topic of this article. I will thus not be concerned with internal whistleblowing or with disclosures made to the appropriate external oversight bodies, as these are generally protected by whistleblower protection legislation (at least on paper). Instead, the focus will lie on unauthorized public disclosures (typically to the media) of classified government documents (typically (but not necessarily ${ }^{3}$ ) by civil servants), that is, on what I call classified public whistleblowing. ${ }^{4}$

There is broad consensus among scholars that whistleblowing requires justification; that is, it constitutes a (pro tanto) wrongful act. One could argue, for example, that unauthorized disclosures constitute a breach of promissory obligations (given that civil servants are often made to swear an oath to respect the confidential nature of the information they encounter in the course of their professional activities) and are, therefore, wrongful. ${ }^{5}$ Others condemn unauthorized disclosures because they believe such disclosures jeopardize national security. This reasoning is particularly prevalent in intelligence circles, but Seana Shiffrin has similarly condemned Snowden's actions as 'negligent with respect to the possible harm he might cause to people and institutions'. ${ }^{6}$ Alternatively, one could appeal to a traditional understanding of civil servants' role responsibilities and

\footnotetext{
${ }^{2}$ Mark Fenster, 'Disclosure's Effects: WikiLeaks and Transparency', Iowa Law Review 97 (2012): pp. 753-807, p. 756.

${ }^{3}$ After all, one of the best-known whistleblowers of today, Edward Snowden, disclosed classified government documents, but was himself not an employee of the government but rather a contractor for Booz Allen Hamilton.

4 'Classified' in the sense that state secrets are involved; 'public' in the sense that the information is disclosed to the public (typically via the media), as opposed to an internal or external supervisory body.

5 Eric R. Boot, 'Classified Public Whistleblowing: How to Justify a pro tanto Wrong', Social Theory and Practice 43(3) (2017): pp. 541-567, pp. 546-8; Sissela Bok, Secrets: On the Ethics of Concealment and Revelation (New York: Vintage Books, 1984), p. 221.

${ }^{6}$ Seana Shiffrin, 'The Moral Neglect of Negligence', in David Sobel, Peter Vallentyne, and Steve Wall (eds.), Oxford Studies in Political Philosophy. Volume 3 (Oxford: Oxford University Press, 2017), pp. 197-228, p. 213.
} 
argue that civil servants owe their superiors strict obedience. Their own political preferences and moral beliefs are not to influence the execution of their tasks. They ought to be impartial and to serve each administration equally well. ${ }^{7}$

Most commonly, however, whistleblowing is deemed wrongful because it involves a wrongful arrogation to oneself of a superior say in public matters, thus failing to respect one of the cornerstones of democratic politics, namely the equal political rights of all citizens. As Thomas Christiano explains, a democratic decision-making process is the only way to reconcile (1) the need for a single system of laws with (2) persistent widespread disagreement, and (3) the requirement of justice to give each an equal say in how we organize our polity. The thought is that the representatives in the democratic legislature can stand for the great variety of political preferences in a polity. The legislature can thus embody the entire citizenry, and its actions may be viewed as 'the pooled exercises of the political rights of all the citizens' ${ }^{8}$ Now, when a whistleblower discloses classified government documents, she is, in effect, arrogating to herself a superior say in the organization of the polity by usurping the power to decide what is and what is not a legitimate state secret, whereas this is properly the prerogative of our democratically elected officials. ${ }^{9}$ This is what Candice Delmas has called political vigilantism. ${ }^{10}$ As Rahul Sagar puts it: '[W] hen unauthorized disclosures occur, vital decisions on matters of national security are effectively being made by private actors, an outcome that violates the democratic ideal that

\footnotetext{
7 See, e.g., Max Weber, 'Politics as a Vocation', in H. H. Gerth and C. Wright Mills (eds.), H. H. Gerth and C. Wright Mills (trans), Essays in Sociology (London: Routledge, 1991), pp. 77-128, p. 95: 'The honor of the civil servant is vested in his ability to execute conscientiously the order of the superior authorities, exactly as if the order agreed with his own conviction'. But see Boot, 'Classified Public Whistleblowing', pp. $551 \mathrm{ff}$, supra note 5.

${ }^{8}$ Thomas Christiano, The Constitution of Equality: Democratic Authority and its Limits (Oxford: Oxford University Press, 2008), p. 248. According to Christiano, the fact that the democratic authority can thus be understood to represent the entire body of citizens, ensuring the equal political rights of each, is what gives it a right to rule. It is also what justifies the citizens' correlative duty to obey.

${ }^{9}$ This is what sets whistleblowing apart from civil disobedience. The very act of whistleblowing immediately, performatively as it were, undoes the decision (made by democratically elected officials) to keep a certain piece of information secret, whereas civil disobedients only wish to protest a particular policy that they oppose and aim to have reformed or repealed entirely by the democratic authority. Whistleblowers may have this same aim, but they, in addition, appropriate for themselves the power to decide what is and what is not a legitimate state secret, whereas this is properly the prerogative of our democratically elected officials.

${ }^{10}$ Candice Delmas, 'The Ethics of Government Whistleblowing', Social Theory and Practice 41(1) (2015): pp. 77-105, p. 94.
} 
such decisions should be made by persons or institutions that have been directly or indirectly endorsed by citizens. ${ }^{11}$

If one finds any (or all, or several) of these arguments convincing and agrees that whistleblowing constitutes a (at least pro tanto) wrongful act, it follows that it is morally correct to maintain a legal prohibition of unauthorized disclosures. From a prudential viewpoint a prohibition is a good idea as well, as it can help prevent misguided or willfully false disclosures. And indeed, though many countries are adopting whistleblower protection laws, protecting those who disclose wrongdoing internally or to the appropriate external supervisory bodies, no country, to my knowledge, grants citizens a right to legal protection against retaliation following an unauthorized disclosure of classified materials to the media. Indeed, the UK's Official Secrets Act, for example, flatly denies (former) members of the security services a right, 'even as a last resort and even in the face of the most serious iniquity, to make a general disclosure'. ${ }^{12}$ Similarly, in the United States, federal government employees in general, let alone whistleblowers from the intelligence community, are not protected from retaliation if the information disclosed had been properly classified. ${ }^{13}$

Yet, though classified public whistleblowing is illegal, it has also become one of our main sources of information concerning government wrongdoing. Given this vital social service provided by whistleblowers, many argue that whistleblowers ought to enjoy some measure of legal protection, lest a chilling effect cause future potential whistleblowers to refrain from disclosing government wrongdoing, leaving the public ignorant of abuse of power, human rights violations, and the like.

The problem is the following: We wish to maintain the legal prohibition of whistleblowing in place but we also wish to provide justified acts of whistleblowing protection against legal sanctions. The former wish seems to exclude one of the most commonly mounted defenses of whistleblowing, namely that unauthorized disclosures ought to enjoy protection based on the whistleblower's

\footnotetext{
${ }^{11}$ Rahul Sagar, Secrets and Leaks: The Dilemma of State Secrecy (Princeton: Princeton University Press, 2013), p. 114; cf. Shiffrin, 'Moral Neglect of Negligence', p. 210, supra note 6.

${ }^{12}$ John Bowers QC, Martin Fodder, Jeremy Lewis, and Jack Mitchell, Whistleblowing: Law and Practice (Oxford: Oxford University Press, 2007), p. 315.

${ }^{13} 5$ USC $\S 2302(\mathrm{~b})(8)(2012)$.
} 
individual right to freedom of expression. Accordingly, when whistleblowing cases are brought before the European Court of Human Rights (ECtHR), the defendant claims that the state has violated her article 10 right to freedom of expression. ${ }^{14}$ Similarly, in the American context, defendants have appealed to their First Amendment rights. ${ }^{15}$ Those who wish to grant whistleblowers legal protection based on a right to whistleblowing included in the right to freedom of expression construe the latter right broadly as a 'right to seek, receive, use and impart information'. ${ }^{16}$ It follows that sanctions against whistleblowers are to be understood as violations of rights, provided certain conditions are met. ${ }^{17}$

This defense has proven problematic as it seems to involve such a chimera as a legal right to break the law. Furthermore, an individualrights-based defense of whistleblowing does not do justice to the fact that the importance of unauthorized disclosures does not so much lie in its being an expression of individual liberty that requires legal protection, but rather in the public importance of such disclosures ${ }^{18}$; the defense ought to, therefore, not be based on individual rights but on whistleblowers' public role.

This brings us to the second most commonly proposed defense of whistleblowers, which will be the topic of the present paper: It is often said that unauthorized disclosures may be justified, and thus warrant legal protection against retaliation, if such disclosures reveal information that is in the public interest. In practice, this would involve setting up a criminal defense for whistleblowers. As a justification defense, such a 'public interest defense' strikes a balance between, on the one hand, recognizing the importance of the democratic allocation of power (and thus maintaining the legal prohibition of whistleblowing) and, on the other hand, providing justified whistleblowers with the necessary legal protection. In this

\footnotetext{
${ }^{14}$ See, e.g., European Court of Human Rights (ECtHR) (Grand Chamber). Guja v. Moldova. 12 February 2008. Application No. 14277/04, $§ 76$.

${ }^{15}$ See, e.g., Mika C. Morse, 'Honor or Betrayal? The Ethics of Government Lawyer-Whistleblowers', Georgetown Journal of Legal Ethics 23 (2010): pp. 421-454.

${ }^{16}$ Open Society Justice Initiative, The Global Principles on National Security and the Right to Information (Tshwane Principles). 2013, Principle 1. Available at https://www.opensocietyfoundations.org/ publications / global-principles-national-security-and-freedom-information-tshwane-principles.

${ }^{17}$ Different scholars and courts list different conditions. Some examples are: harm minimization, exhaustion of legal alternatives, the whistleblower's good faith, and of course that the disclosed information must contain evidence of wrongdoing of public concern.

${ }^{18}$ Eric R. Boot, 'No Right to Classified Public Whistleblowing', Ratio Juris 31(1) (2018): pp. 70-85, p. 71.
} 
manner, we may continue to benefit in the future from disclosures that call the authorities to account when it oversteps its bounds.

The problem with this defense of justified whistleblowing, however, is that the operative term - the public interest - is all too often left unclarified. Political philosophers, ${ }^{19}$ legal $^{20}$ and public administration $^{21}$ scholars, whistleblower protection laws, ${ }^{22}$ national $^{23}$ and international $^{24}$ guidance documents, courts ${ }^{25}$ - all agree that a breach of state secrecy by disclosing classified documents is justified if it serves the public interest. None of them, however, provide a definition of what the public interest exactly is, nor do they explain how we may determine it; at the most, an ad hoc list of offences is drawn up, the disclosure of which would be in the public interest.

This is problematic because it leaves potential whistleblowers without sufficient certainty that their disclosures will be covered by the defense, leading many to err on the side of caution and remain silent, depriving the public of much-needed information. Failing an agreed upon definition of the public interest or a process to determine it, it is up to judges to determine whether a particular disclosure is in the public interest. This, predictably, has led to the critique

\footnotetext{
${ }^{19}$ Bok, Secrets, p. 219, supra note 5; Boot, 'Classified Public Whistleblowing', pp. 557-58, supra note 5; Candice Delmas, 'The Civic Duty to Report Crime and Corruption', Les ateliers de l'éthique 9(1) (2014): pp. 50-64, p. 62; Manohar Kumar and Daniele Santoro, 'A Justification of Whistleblowing', Philosophy and Social Criticism 43(7) (2017): pp. 669-684, pp. 8ff.; Sagar, Secrets and Leaks, p. 13 supra note 11.

${ }^{20}$ Yochai Benkler, 'A Public Accountability Defense for National Security Leakers and Whistleblowers', Harvard Law and Policy Review 8 (2014): pp. 281-326; Dimitrios Kagiaros, 'Protecting "National Security" Whistleblowers in the Council of Europe: An Evaluation of Three Approaches on How to Balance National Security with Freedom of Expression', The International Journal of Human Rights 19(4) (2015): pp. 408-428.

${ }^{21}$ Mark Bovens, The Quest for Responsibility: Accountability and Citizenship in Complex Organisations (Cambridge: Cambridge University Press, 1998), pp. 163ff.

22 The UK Public Interest Disclosure Act; the Dutch Wet huis voor klokkenluiders (House for Whistleblowers Act), article 1(d).

${ }^{23}$ UK Information Commissioner's Office, The Public Interest Test: Freedom of Information Act (2016). Available at: https://ico.org.uk/media/for-organisations/documents/1183/the_public_interest_test. pdf.

24 Tshwane Principles, Principle 37, supra note 16.

${ }^{25}$ E.g., ECtHR, Guja v. Moldova, § 74, supra note 14. Specifically, the Court considered whether the public interest in upholding secrecy was strong enough to warrant a violation of the whistleblower's Article 10 right to free speech, or that, instead, the public interest in disclosure argued in favor of upholding his Article 10 right.
} 
that applications of the public interest in whistleblowing cases are ad hoc $^{26}$ and demonstrate 'judicial idiosyncrasy'. ${ }^{27}$ The present paper, therefore, sets out to (1) provide some clarity concerning the public interest, and (2) to ascertain the extent to which a public interest defense for whistleblowers is feasible and desirable. Accordingly, the paper will be structured as follows: Section II will give an overview of three common understandings of the public interest (aggregative, procedural, and unitary) and explain why they are problematic. Subsequently, Section III presents a more promising alternative, namely the civic account of the public interest, which I will defend. In brief, it argues that public interests are those interests that we all share in our role as members of the public. Next, Section IV provides a description of how a public interest defense for whistleblowing could work, given the definition expounded in Section III. I argue that, for the defense to be fully available to the whistleblower, her disclosure must meet three conditions: the public interest condition, the ultimum remedium (or last resort) condition, and the minimize harm condition. If the first of these conditions is not met, the defense is unavailable. If, instead, one of the latter two conditions is not met (or if neither of them is met), the defense will likely serve to mitigate the sentence rather than function as a full defense. Section V discusses three possible objections to the public interest defense set out in Section IV: the epistemic constraints objection, the incommensurability of interests objection, and the reasonable disagreement objection. Section VI concludes.

\section{THEORIES OF THE PUBLIC INTEREST}

Though appeals to the public interest are incredibly common in law, politics, and ordinary speech, they are also made rather casually. As a consequence, what is meant by 'the public interest' typically remains unclear. Some, however, have held that this lack of clarity is a necessary characteristic of the concept, dismissing it altogether as vacuous. ${ }^{28}$ Others consider the concept a convenient tool for the

\footnotetext{
${ }^{26}$ Aileen McHarg, 'Reconciling Human Rights and the Public Interest: Conceptual Problems and Doctrinal Uncertainty in the Jurisprudence of the European Court of Human Rights', The Modern Law Review 62(5) (1999): pp. 671-696, p. 683.

${ }^{27}$ David Lewis, 'Is a Public Interest Test for Workplace Whistleblowing in Society's Interest?', International Journal of Law and Management 57(2) (2015): pp. 141-158, p. 143.

${ }^{28}$ Glendon Schubert, The Public Interest (Glencoe, Ill.: Free Press, 1960), pp. 223-24.
} 
powerful to present their own factional interests as public interests. ${ }^{29}$ Furthermore, some wonder whether the concept, which appears to presuppose an interest common to all, can be of any use in contemporary pluralistic societies. ${ }^{30}$ Finally, critics worry that the concept may be abused by demagogues demanding individual sacrifices for the greater common good. ${ }^{31}$ Because of these concerns, the concept has largely fallen out of fashion in legal and political philosophy in recent decades. As a consequence, the concept has retained its problematic protean nature, being used differently by different people in different contexts. This section will discuss the three main public interest theories: the aggregative, the procedural, and the unitary approaches. ${ }^{32}$ Each of these, however, has serious drawbacks, prompting me to sketch a more promising account in Section III.

\section{A. The Aggregative Account}

According to Jeremy Bentham, a community consists simply of the aggregate of its members. It follows that that the interest of the community then is, what? - the sum of the interests of the several members who compose it'. ${ }^{33}$ This is also referred to as Bentham's 'compositionalism'. ${ }^{34}$ Whether a particular action, policy, or law is conducive to one's interest depends on its utility: 'that property in any object, whereby it tends to produce benefit, advantage, pleasure, good, or happiness ... or (what comes again to the same thing) to prevent the happening of mischief, pain, evil, or unhappiness to the party whose interest is considered, ${ }^{35}$ The question whether a par-

\footnotetext{
${ }^{29}$ Karl Marx and Friedrich Engels, 'From “The German Ideology”: Chapter One, "Feuerbach"”, in Joseph O’Malley (ed.), Terrell Carver and Daniel Blank (tran.), 'German Ideology' Manuscripts: Presentation and Analysis of the 'Feuerbach Chapter' (New York: Palgrave, 2014), p. 183.

${ }^{30}$ Ian O'Flynn, 'Deliberating About the Public Interest', Res Publica 16(3) (2010): pp. 299-315, p. 300.

${ }^{31}$ Jane Mansbridge, 'On the Contested Nature of the Public Good', in Walter W. Powell and Elisabeth Stephanie Clemens (eds.), Private Action and the Public Good (New Haven: Yale University Press, 1998), pp. 3-19, p. 4.

32 For this list of public interest theories, I am indebted to both Virginia Held, The Public Interest and Individual Interests (New York: Basic Books, 1970), pp. 42-46 and Mansbridge, 'Contested Nature of the Public Good', pp. 9-11, supra note 31, though I depart from both of their lists of categories at times.

${ }^{33}$ Jeremy Bentham, An Introduction to the Principles of Morals and Legislation, J. H. Burns and H. L. A. Hart (eds) (Oxford: Oxford University Press, 1996), p. 12.

${ }^{34}$ Gerald J. Postema, 'Interests, Universal and Particular: Bentham's Utilitarian Theory of Value', Utilitas 18 (2006): pp. 109-133, p. 111.

${ }^{35}$ Bentham, An Introduction to the Principles of Morals and Legislation, p. 12, supra note 33.
} 
ticular law or policy is in the public interest thus comes down to determining its effects on the happiness or welfare of each of the individual members that together constitute the public and tallying the results. If, on balance, the law or policy benefits more individuals than are harmed by it, this will demonstrate the 'general good tendency of the act, with respect to the total number or community of individuals concerned'. ${ }^{36}$

It follows that there is no distinct 'public' with its own interests separate from the private interests of the sundry individuals that together make up the public. Rather, the public interest is determined simply by aggregating the private interests of the individual members of the public; if a policy is in the private interest of the majority of those individuals, then it is in the public interest.

The problem with this view is that we often want to distinguish between majority interests and the public interest. This concern points toward the idea that the public interest is a moral concept. As such, it cannot be derived from the empirical observation that the interests of some individuals outnumber the interests of others. When we ask 'Is $x$ in the public interest?' we want to know something else than whether $x$ is in the interest of the majority. Furthermore, the aggregative method of determining the public interest may be considered morally objectionable in that it appears to render minority interests inferior to majority interests, irrespective of the content of those interests.

Finally, there is the familiar problem posed by social choice theory, namely that when voters have to make a choice between three or more alternatives $(A, B$, and $C)$, there is no fair and rational way to determine which of these is preferred by a majority, that is, to convert voters' preferences into a social decision. ${ }^{37}$ In its simplest form, Kenneth Arrow's impossibility theorem, which demonstrates this problem, is as follows: suppose three people - Mary, Michael,

\footnotetext{
${ }^{36}$ Ibid., p. 40.

${ }^{37}$ See, e.g., Kenneth J. Arrow, Social Choice and Individual Values (New Haven: Yale University Press, 2nd ed. 1963).
} 
and Molly - are to rate three alternatives (e.g., policies or political candidates). The following matrix shows their individual preferences:

\begin{tabular}{llll}
\hline & A & B & C \\
\hline Mary & 1 & 2 & 3 \\
Michael & 3 & 1 & 2 \\
Molly & 2 & 3 & 1 \\
\hline
\end{tabular}

The matrix shows that a majority prefers $A$ to $B$ (Mary and Molly), and $B$ to $C$ (Mary and Michael). It would logically follow that a majority therefore also prefers $A$ to $C$. Yet, as we can see, a majority in fact prefers $C$ to $A$ (Michael and Molly). From this matrix, one could thus both infer that a majority prefers $A$ to $C$ and that a majority prefers $C$ to $A$, which is quite impossible. Next to the moral objections to the aggregative theory mentioned above, there is thus also the problem of the logical impossibility of distilling a collective ordering of preferences from the aggregate of individual preferences.

\section{B. The Procedural Account}

The procedural account holds that the public interest coincides with the result of a democratic decision-making procedure. The latter can be interpreted either in a pluralist or in a more deliberative manner. In an ideal pluralist scheme, democratic politics consists of a fair contest between interest groups, each seeking to influence the political agenda, at the expense of others. Individuals and interest groups are focused on promoting their own self- or group interest, and whatever is the result of this contest for political influence which must be ensured to be fair, i.e., all interests ought to receive equal consideration ${ }^{38}$ - is the public interest. Thus, as in the aggregative account, the public interest is distilled from private interests, but the manner in which private interests lead to the public interest is different: It is not a matter of calculus, as it were, but rather of democratic competition.

The question is, however, whether such a profusion of competing private interests can ever lead to a genuinely public interest or must

\footnotetext{
${ }^{38}$ Robert A. Dahl, Democracy and Its Critics (New Haven: Yale University Press, 1989), p. 297.
} 
instead remain, to speak with Rousseau, 'nothing but a sum of particular wills'. ${ }^{39}$ Such concerns might lead us to adopt instead a deliberative democratic approach to the public interest. Deliberative democrats argue that political debate ought not to be focused on private or group interests, but instead on the common good. ${ }^{40}$ In fact, however, what they often argue is that deliberators still start out with their own private interests, but that the deliberative process - in which one has to, among other things, give reasons for one's proposals that may also be acceptable to others - can transform those private interests in such a way that the final result of deliberation (the law or policy decided upon) will be in the public interest. Thus, according to the deliberative ideal, I cannot, for example, appeal to the desire to be wealthier come what may in defending a particular policy that will help me reach that goal. Instead, I must offer reasons that others may find convincing as well, reasons that do not hinge on my desire for affluence. ${ }^{41}$ It is, therefore, not the case that deliberative democrats start from conceptions of the public interest rather than self-interest. Instead, as Ian O'Flynn has perceptively pointed out, 'the hope is that deliberation will transform special interests into public interests'. ${ }^{42}$ The starting point, even for deliberative democrats it seems, is still a conflict of private (and group) interests. ${ }^{43}$ The worry is, therefore, the same as with pluralist theories of democracy, namely whether they can truly deliver a public interest.

In addition, one might take issue with the strong procedural nature of this approach to the public interest. Benhabib, for example, argues that 'what is considered in the common interest of all results

\footnotetext{
${ }^{39}$ Jean-Jacques Rousseau, 'Of the Social Contract', in Victor Gourevitch (ed. and trans.), The Social Contract and Other Later Political Writings (Cambridge: Cambridge University Press, 1997), pp. 39-152.

${ }^{40}$ See, e.g., Joshua Cohen, 'Deliberation and Democratic Legitimacy' in Alan Hamlin and Philip Pettit (eds), The Good Polity: Normative Analysis of the State (Oxford: Basil Blackwell, 1989), pp. 17-34.

${ }^{41}$ Ibid., p. 24.

42 O’Flynn, 'Deliberating About the Public Interest', p. 308, supra note 30.

${ }^{43}$ See, e.g., Seyla Benhabib, 'Toward a Deliberative Model of Democratic Legitimacy', in Seyla Benhabib (ed.), Democracy and Difference: Contesting the Boundaries of the Political (Princeton: Princeton University Press, 1996), pp. 67-94, p. 73: 'the deliberative model of democracy proceeds not only from a conflict of values but also from a conflict of interests in social life'. Also see Jane Mansbridge, James Bohman, Simone Chambers, David Estlund, Andreas Føllesdal, Archon Fung, Cristina Lafont, Bernard Manin, and José Luis Martí, 'The Place of Self-Interest and the Role of Power in Deliberative Democracy', Journal of Political Philosophy 18 (2010): pp. 64-100, in which a number of prominent deliberative democratic theorists argue for a greater role of self-interest in democratic deliberation.

${ }^{44}$ Ibid., p. 69.
} 
from processes of collective deliberation' ${ }^{44}$ And Cohen maintains that 'the interests, aims and ideals that comprise the common good are those that survive deliberation,, 45 and that 'what is good is fixed by public deliberation, and not prior to it'. ${ }^{46}$ But how can deliberative theorists claim both that deliberation ought to be focused on the public interest and that the public interest is the result of that very same deliberation? ${ }^{47}$ The former claim seems to imply that the public interest exists independently of deliberation, whereas this is denied by the latter claim. In any case, if we wish to retain the public interest as a moral concept, we cannot simply equate it with the result of deliberation (or of the free and fair competition of interests), which is an empirical matter, after all. Furthermore, we can never be certain that citizens will deliberate judiciously and that the result will be satisfactory. ${ }^{48}$ Finally, even if we assume ideal conditions for deliberation are present, and citizens exchange arguments with one another in a reasonable and charitable manner in conditions that are free and equal, then we still have no guarantee that they will agree which policy most serves the public interest.

\section{The Unitary Account}

Having discussed the two most prevalent theories of the public interest, we can see that they, though quite different, share a common problem: They both fail to sufficiently recognize that the public interest is a substantively moral concept that is identifiable independently both of democratic processes and of the majority interest. To avoid this problem, we may consider the straightforwardly normative unitary theory of the public interest, as found in the works of Aristotle, for example. As is well known, Aristotle viewed the state as a kind of partnership or association. Like any partnership, it is set up for the purpose of realizing a certain good common to all members. As it is the most encompassing of all partnerships, the good pursued by the state is the most comprehensive good. ${ }^{49}$ The

\footnotetext{
45 Cohen, 'Deliberation and Democratic Legitimacy', p. 25, supra note 40.

${ }^{46}$ Ibid., p. 29; cf. Craig Calhoun, 'The Public as a Social and Cultural Project' in Walter W. Powell and Elisabeth Stephanie Clemens (eds), Private Action and the Public Good (New Haven: Yale University Press, 1998), pp. 20-35, p. 32.

${ }^{47}$ O’Flynn, 'Deliberating About the Public Interest', p. 302, supra note 30.

${ }^{48}$ Ibid., p. 308.

${ }^{49}$ Aristotle, Politics, H. Rackham (trans.), (Cambridge (Mass): Harvard University Press, 1944), I.i 1252a1-6.
} 
end at which the state aims (the good it strives to bring about) coincides with the end each individual ought to strive towards: 'the best life, whether separately for an individual or collectively for states, is the life conjoined with virtue furnished with sufficient means for taking part in virtuous actions', that is, human flourishing (eudaimonia). ${ }^{50}$ There is thus, for Aristotle, no conflict between the good of individuals and the common good of the polity as a whole.

Unitary theories of the public interest, as found in Aristotle (but also in Plato and Aquinas, for instance) do not derive the public interest from people's private interests, but rather from a comprehensive moral theory that applies equally to private and to public interests. Consequently, a law or policy cannot be in the public interest if it is not also in the interest of all, and it cannot truly be in the interest of a certain individual if it is not also in the public interest. In other words, there can be no justifiable conflict between individual interests and the public interest. ${ }^{51}$ Contemporary liberals generally find this conception untenably problematic, given its predisposition to paternalism - after all, any assertion of a private interest that does not coincide with the public interest is dismissed as misguided - and its exclusion of conflicting interests. In today's diverse societies there can be no presumption of unanimity concerning individual interests, and it is therefore problematic to assume a unity between the individual and the collective good.

\section{THE CIVIC ACCOUNT ${ }^{52}$}

One of our concerns with the aggregative and the procedural theories of the public interest was that they did not bring about genuinely public interests. They are concerned with the 'will of all' rather than the 'general will'. So-called 'common interest theorists' evade this problem as they consider only those interests to be public interests that are shared by all members of the public. The obvious

\footnotetext{
${ }^{50}$ Ibid., VII.i 1323b40-1324a2. Cf. VII.ii 1324a5-8: 'On the other hand it remains to say whether the happiness of a state is to be pronounced the same as that of each individual man, or whether it is different. Here too the answer is clear: everybody would agree that it is the same'.

${ }^{51}$ Held, The Public Interest and Individual Interests, p. 136, supra note 32.

52 Note that the account of the public interest I develop here, differs somewhat from my previous, very brief treatments of the subject in Boot, 'Classified Public Whistleblowing', supra note 5 and Boot, 'No Right to Classified Public Whistleblowing', supra note 18.
} 
critique of this position is that such interests are bound to be extremely rare (if they exist at all), rendering the concept nearly meaningless. Even a law prohibiting (or limiting) the pollution of the air and water (one would at least expect the interests in clean air and water to be on the list of interests shared by all) may not be in everyone's interests. After all, some people profit from polluting the air and water, and the damages to their health (from breathing polluted air and drinking polluted water) may not outweigh the profits to be made from their polluting enterprises. The commoninterest approach would, therefore, have to conclude that protecting the air and water is not in the public interest. ${ }^{53}$

This implausible conclusion seems to instantly discredit the common interest approach. Yet, if we follow Brian Barry's account, we may still be able to circumvent this conclusion. He points out that disagreements over policy often spring from different people judging the policy from the perspective of a different 'role'. For example, a policy to lower the speeding limit in a particular neighborhood may be contrary to A's interests as a motorist, but at the same time in B's interest as a parent of small children. Depending on the role we occupy, we may judge a policy differently. Such a conflict of interests can even be present within a single individual. After all, with respect to a given situation, we may have different interests as we may simultaneously occupy different roles in relation to it (home owner, parent, employee, nature lover, and so forth).

The next step of the argument is to point out that the only role we all occupy is that of a member of the public. ${ }^{54}$ In determining wherein the public interest consists, we must therefore look to 'those interests which people have in common qua members of the public'. 55 Returning to our earlier example, we may acknowledge that legislation aimed at protecting the air and water from (excessive) pollution is not in the interest of some qua members of polluting industries. But, as members of the public, they share an interest in clean air and water with all other members. Legislation aimed at ensuring these goods is,

\footnotetext{
${ }^{53}$ Robert E. Goodin, 'Institutionalizing the Public Interest: The Defense of Deadlock and Beyond', The American Political Science Review 90 (1996): pp. 331-343, p. 338.

54 Brian Barry, 'The Public Interest', Proceedings of the Aristotelian Society 38 (1964): pp. 1-18, pp. 14-5.

55 Brian Barry, Political Argument (London: Routledge \& Kegan Paul, 1965), p. 190.
} 
therefore, in the public interest 'in the sense that it is in everyone's interest qua member of the public'. ${ }^{56}$ Much like Rousseau's 'citizen' who only has a general will, as opposed to the 'man' who merely follows his own particular will, ${ }^{57}$ in our capacity as member of the public we will be inclined to favor policies that are in the interest of all members of society rather than exclusively in our own private interest (qua industrialist, home owner, employee, etcetera).

Barry's theory of the public interest thus avoids many of the pitfalls of the rival theories discussed earlier. It does not assume a perfect unity between individual and community interests, as the unitary theory does, and can thus accommodate a multitude of different and often conflicting private interests in society, which is an advantage of the aggregative and procedural accounts. Contrary to those latter two approaches, however, the public interest identified by Barry is genuinely public. He holds that if we want to promote the public interest, we must promote interests that all share as members of the public, whereas the aggregative approach aims to simply maximize private interests for all as much as possible, and the procedural approach hopes to distill shared interests from the profusion of private interests through deliberation. Furthermore, Barry's approach occupies attractive middle ground between the comprehensive moral position advocated by the unitary theory and the subjectivist nature of the aggregative and procedural theories. The public interest is not simply the aggregate of private interests nor is it to be equated to the outcome of deliberation. The public interest, on Barry's account, is still a moral concept in the sense that private interests are excluded from its determination: In determining the public interest, we ought to pay heed only to our interests as members of the public. Yet, it does not presuppose wide agreement over a comprehensive moral theory as the unitary theory seems to do.

Finally, in identifying the public interest with the interests we share in our role as citizens, Barry's account coincides nicely with

\footnotetext{
${ }^{56}$ Ibid., p. 224. Note that, contrary to the unitary theory, this account of the public interest does allow for the possibility of $x$ being contrary to my private interests but still in the public interest. There is thus no presupposed unity between public and private interests.

${ }^{57}$ Rousseau, 'Of the Social Contract', Bk. I, Ch. 7 [7], supra note 39. Cf. Joshua Cohen, Rousseau: A Free Community of Equals (Oxford: Oxford University Press, 2010), p. 54: 'As citizens, they are not to rely on their private will in assessing regulations or deciding whether to comply, nor are they to balance considerations of personal advantage and of the common good. Instead, they are to deliberate about what the laws should be by reference to considerations of the common good (common interests), and to deliberate about conduct by giving first consideration to reasons of the common good'.
} 
whistleblower legislation and guidance documents, which state that the fact that disclosure may serve the whistleblower's private interests, is not a sufficient (or even a necessary) reason for disclosure, as 'what may serve those private interests does not necessarily serve a wider public interest', which alone can justify disclosure. ${ }^{58}$

Stating, with Barry, that the public interest consists of those interests we share qua members of the public, is a good first step, but it is not enough for our purpose, which is to assess the feasibility of a public interest defense for justified cases of whistleblowing. For what are the interests we share as members of the public? Barry does not further specify this. But one thing we now know is that the public interest does not result from the sundry private interests we may have. If something (a law or policy) is in the public interest, this does not mean that it aims to realize certain private aims that specific individuals may have. If a law or policy serves the common good (a term closely related to the public interest ${ }^{59}$ ), this does not mean that the law or policy is aimed at realizing a particular conception of the good (or even various conceptions of the good) individuals may have. It seems to me that the only interests we can reasonably be said to all share in our role as members of the public are interests in conditions that make it possible for each of us to develop and strive to realize our own values, objectives, and life plans. Or, to put it another way, if something is in the public interest, then it is instrumental for the realization of individuals' private interests, provided the pursuit of these interests does not reduce the ability of other members of the community to pursue theirs. This civic account of the public interest obviously does not deny that the private interests of individual members of the community may differ from one another and may even conflict; all it states is that the interests we share as members of the community are interests in conditions that need to be in place if all members are to be able to pursue their own interests. ${ }^{60}$ For example, the unchecked arbitrary exercise of

\footnotetext{
${ }^{58}$ Office, The Public Interest Test, p. 7, supra note 23.

59 Though some have argued that the public interest is more minimalist than the common good, concerning chiefly material wellbeing, whereas the common good also concerns people's moral character and personal development (Bruce Douglass, 'The Common Good and the Public Interest', Political Theory 8 (1980): 103-117.).

${ }^{60}$ For this elaboration of Barry's understanding of the public interest I am indebted to John Finnis's work on the common good, which he views as synonymous with the public interest: John Finnis, Natural Law and Natural Rights, 2nd Edition (Oxford: Oxford University Press, 2011), Chapter 6.
} 
power by a ruler makes it very problematic to formulate a life plan, let alone realize it, given that we do not know for sure that what is permissible today won't be decreed impermissible tomorrow. Hence, the shared interest in the rule of law. Similarly, without a sphere of protected free agency, both the formulation and the realization of a life plan become extremely difficult. We thus share an interest in fundamental human rights. ${ }^{61}$ Further examples of interests we share in our capacity as members of the public include interests in legal certainty, the separation of powers, and political accountability.

Of course, this civic account of the public interest, which expands upon Barry's approach to the public interest, does not do away with all problems. In particular, it remains unclear what to do when the several interests we share as members of the public are in conflict, such as the interests in privacy and security. For now, we can say two things in reply: First, the fact that public interests may be in conflict does not demonstrate that the idea of the public interest itself is somehow incoherent. Indeed, as O'Flynn points out, 'the values of freedom and equality can also conflict. But no one seriously suggests that we should give up on those values simply because of the many tensions that can arise between them'. ${ }^{62}$ Second, Barry points out that 'interest' is a comparative concept: "Being in someone's interest' is at least a triadic relationship between a person and at least two policies, ${ }^{63}$ Thus, when we ask if a given policy proposal is in the public interest, we are asking whether it is more in the public interest than a given alternative. So, though there may be conflicting interests all members of the public share, it may still be possible to judge whether policy proposal $x$ better serves the public interest than proposal $y$ (for example, if the benefits to privacy promised by proposal $x$ are quite large while the benefits to the conflicting interest of security ${ }^{64}$ promised by proposal $y$ are rather small, then it

\footnotetext{
${ }^{61}$ Socioeconomic rights as well as civil and political rights. After all, a certain level of physical wellbeing is a necessary precondition for the possibility of pursuing one's interests and realizing one's objectives.

${ }^{62}$ O’Flynn, 'Deliberating About the Public Interest', p. 313, supra note 30.

${ }^{63}$ Barry, Political Argument, p. 192, supra note 55.

${ }^{64}$ Privacy and security are here to be understood as specifications of the more general public interest in human rights.
} 
would seem proposal $x$ is more in the public interest than proposal $y$ ).

Having thus expounded the civic account of the public interest, I will now turn to the question what a public interest defense for justified whistleblowing might look like.

\section{A PUBLIC INTEREST DEFENSE}

First of all, the public interest defense would be a justification defense. According to the most common understanding, when one claims one's action was justified, one concedes criminal wrongdoing, but denies that it was, all things considered, the wrong thing to do (e.g., $A$ admits to having assaulted $B$, but argues that her action ought to be considered justified, given the fact that $B$ had attacked her and she acted out of self-defense). By comparison, when one invokes an excuse, one concedes that one's act was wrongful (both criminally and morally), but seeks to avoid the attribution of responsibility for the act (e.g., $A$ admits to having wrongfully assaulted $B$, but her mental condition is such that it would be wrong to attribute responsibility for the act to her). ${ }^{65}$ In practice, stating that unauthorized disclosures may be justified, means, according to this understanding of justification, that the act of whistleblowing remains criminal. This enables the law to continue to attach significant risks to whistleblowing, precluding (to an extent) the occurrence of frivolous and willfully false disclosures, while at the same time offering protection to those cases of whistleblowing that are justified. It, therefore, achieves the right balance between the prevention of undesirable acts and the protection of justified whistleblowing, allowing the latter to continue to fulfill its vital public function of bringing government wrongdoing to light.

In order to assess whether a particular whistleblower's disclosure of classified information to the media is justified, and ought thus not to incur any sanction, the judge must ask whether the release of the information did, on balance, more good than harm to the interest we share as members of the political community in those conditions that need to be in place if all members are to be able to pursue their own

\footnotetext{
${ }^{65}$ For such an account of the distinction between justifications and excuses, see, e.g.: J.L. Austin, 'A Plea for Excuses: The Presidential Address', Proceedings of the Aristotelian Society 57 (1956): pp. 1-30, p. 2; George P. Fletcher, Rethinking Criminal Law (Oxford: Oxford University Press, 2000), p. 759.
} 
interests (e.g., the rule of law, the separation of powers, human rights). She must determine, in other words, whether disclosure or continued secrecy better serves those conditions. If the latter - if, in other words, the harm to the public interest caused by her disclosures likely outweighs the benefit to the public interest that would result from making the classified information public - then the whistleblower's actions are not covered by the defense. If the former, then her actions are covered by the defense, and criminal sanctions should either not be imposed at all or should be mitigated (depending on whether the further conditions of the defense, to be expounded in a moment, are met). Of course, this does not altogether do away with the problem of judicial discretion mentioned in Section I. But it can structure that discretion by providing a framework for it. For example, the civic account of the public interest already excludes certain interests from consideration in the legal balancing test. Furthermore, it can help us determine which shared interests ought to be given a greater weight in the balancing test. One can imagine if the public interest was simply determined as 'interests shared by all' that it would be difficult to attach different weights to different public interests (as they all meet the key criterion of 'being shared by all'). Instead, I have suggested that the public interest consists in the interest in the conditions that make it possible for each of us to develop and strive to realize our own values, objectives, and life plans. In realizing this possibility, some of these conditions are more important than others. Accordingly, we can attach varying weights to our various shared interests in accordance with how instrumental the conditions concerned are in facilitating the realization of our private interests. For example, good infrastructure is certainly in the public interest, for various reasons (because it makes trade possible, because it allows people to travel). Yet, if the only way to expand the current congested road network were to build a road through a natural reserve, which would seriously contaminate the most important clean water reservoir of the country, then such expansion would not be in the public interest, given that clean water is a more fundamental condition for the possibility of pursuing our private interests (hereinafter: 'a more fundamental condition' for short) than the ability to travel more quickly. 
Of course, though excessive judicial discretion (where applications of the public interest become arbitrary and potential whistleblowers, consequently, cannot with any certainty know in advance how the term 'public interest' will be applied in their case) may thus be limited, some discretion will necessarily remain. It seems, for example, that different judges may reasonably disagree whether privacy is more in the public interest than security. Still, in the case of a real threat to national security, security will most likely be granted greater weight than privacy, showing that it is a more fundamental condition than privacy. After all, being alive and healthy is the sine qua non for the pursuit of our interests. However, determining where the public interest lies in a whistleblowing case will also require us to look at the gravity of the harm to security likely to ensue from disclosure and the significance of the benefit to privacy. If the former is quite small and the latter is rather large, then the public interest is ultimately best served by disclosure rather than continued secrecy. If, by contrast, the harm to national security is great and the benefit to privacy rather small, then the disclosure is not in the public interest. Finally, if the harm to national security and the benefit to privacy are judged to be more or less equal, then the public interest is best served by continued secrecy, given the greater weight attributed to national security.

In order to get a clearer idea of the proposed public interest defense, let us compare it with the 'objective list approach', which is dominant in legal practice and scholarship. ${ }^{66}$ The latter approach simply provides a list of values that may justify disclosures to the media of secret government actions, laws, or policies that threaten those values, if other avenues for addressing wrongdoing (internally, or externally to an independent oversight body) have been fruitlessly exhausted. Typically included on the list are, among others, human rights, political accountability, national security, and public health. ${ }^{67}$ There are two problems with this approach. Firstly, it does not do away with the problem it claims to solve. The (correct) point made

\footnotetext{
${ }^{66}$ Note that I am not referring here to objective list theories of wellbeing as discussed by philosophers, particularly utilitarians. Instead, I am simply referring to the common approach found in whistleblower protection legislation and guidance documents to draw up lists of values that may warrant disclosure.

${ }^{67}$ See, for example, Benkler, 'A Public Accountability Defense for National Security Leakers and Whistleblowers', pp. 308-9, supra note 20; Kagiaros, 'Protecting "National Security" Whistleblowers in the Council of Europe', p. 420, supra note 20; Tshwane Principles, Principle 10, supra note 16; UK Information Commissioner's Office, The Public Interest Test, p. 6, supra note 23.
} 
by the objective list proponents is that we need to provide some more clarity for potential whistleblowers regarding the fundamental concept of the public interest. However, their approach fails to do so. After all, the various values on this list (human rights, public health, national security, etc.) may still conflict. The whistleblower will still have to judge for herself whether, for example, the benefits to privacy outweigh the harm to security brought about by her disclosure. In short, the uncertainty it set out to remove remains, because the objective list approach does not provide us any guidance in cases of conflict. ${ }^{68}$ The whistleblower thus still has no way of determining which value ought to be granted more weight. My approach does provide such guidance, as it does not simply provide an ad hoc list of values possibly warranting disclosure; instead it gives a reason why those values are on the list, namely that they are conditions that need to be in place if all members are to be able to pursue their own interests. This same reason also allows the whistleblower to attach different weights to different values and thus to determine which value is a 'more fundamental condition' (as demonstrated in the preceding paragraph). Secondly, a limited list of specific values also risks being too rigid and thus not adaptable enough to new developments. Confronted with a new type of wrongdoing threatening a value not (yet) on the list, the objective list approach must deny protection to the whistleblower disclosing it. Again, my proposed account of the public interest does not suffer from this drawback, because it does not provide an ostensibly complete list of values justifying disclosure in the public interest, but instead a theory of the public interest that is equally applicable to new developments.

Still, even with the proposed account of the public interest, it might be difficult for, say, the average civil servant to ascertain whether the public interest would be better served by disclosure or continued secrecy. Of course, she could consult the relevant case law to get a sense of when the courts tend to grant protection to whistleblowers and when they do not. Yet, the case law may not be

\footnotetext{
${ }^{68}$ Indeed, some of its proponents admit as much: Kagiaros 'Protecting "National Security" Whistleblowers in the Council of Europe', p. 421, supra note 20.

${ }^{69}$ Indeed, Lewis, 'Is a Public Interest Test for Workplace Whistleblowing in Society's Interest?' supra note 27 , has shown the case law concerning the public interest in whistleblowing cases to be quite inconsistent.
} 
consistent ${ }^{69}$ and the employee may also not be aware of the relevant rulings. In the latter case, the potential whistleblower may seek independent (legal) advice from the confidential adviser at one's workplace. As an alternative, the Netherlands has set up a so-called 'House for Whistleblowers' where potential whistleblowers can go for free and strictly confidential legal advice. Yet, even when such precautions are taken, mistakes can still be made: Information may be disclosed, which the whistleblower believed would serve the public interest but which, in the end, does more harm than good to the public interest (or which, perhaps, does not point to government wrongdoing at all). Should a whistleblower in such a case still be allowed to invoke the public interest defense or should it only be available to those whose disclosures actually reveal wrongdoing and serve the public interest? Given the risks of a chilling effect, leading potential whistleblowers to err on the side of caution and thus to refrain from disclosing information even when it truly does reveal government wrongdoing, it would be best to allow the defense to be invoked in the former case as well, provided the information revealed could have reasonably been believed to reveal grave government wrongdoing. This concession need not lead to excessive whistleblowing, ${ }^{70}$ however, because the 'reasonable belief test is not only subjective, but also objective. Not only must the whistleblower herself have actually believed that her disclosure would be in the public interest (I will explain why I include this subjective test in a moment.), but this subjectively held belief must, in addition, have been objectively reasonable. We must ask, in other words, whether a reasonable person $^{71}$ would have believed that the information demonstrated grave government wrongdoing that threatened one of the interests shared as members of the public, that is, threatened one of the key institutions that make it possible for each of us to develop life plans and strive to realize them. Furthermore, was it reasonable to believe that the benefit of informing the public of this wrongdoing

\footnotetext{
${ }^{70}$ I thank an anonymous reviewer for Law and Philosophy for pressing me on this point.

${ }^{71}$ The description of the 'reasonable belief test here relies on Arthur Ripstein's account of the 'reasonable person' as the person 'who exercises appropriate foresight in deciding whether to engage in activities that impose risks on others'. To do so involves taking both the benefits (in this case, to the public interest) and the likely costs into account (Arthur Ripstein, 'Equality, Luck, and Responsibility', Philosophy \& Public Affairs 23 (1994): pp. 3-23, pp. 11-12).

${ }^{72}$ Think, for example, of a disclosure that would also reveal the identity of undercover intelligence officers, exposing them to grave harm.
} 
would outweigh the possible detriment to those institutions or to particularly weighty private interests, ${ }^{72}$ which could ensue from disclosing the information? If the answer is 'no', then the objective reasonable belief test is not passed and the defense should therefore not be available to the whistleblower. This should filter out frivolous and deliberately false 'disclosures'. If, however, the whistleblower did all that could reasonably be expected of her to be sure that her disclosure would be in the public interest - i.e., assure herself that the information does indeed demonstrate grave government wrongdoing as well as engage conscientiously in the weighing exercise described above - if, in other words, her belief that her disclosure served the public interest was reasonable, then the defense ought still to be available.

Furthermore, I acknowledge that this approach may lead to some false positives (i.e., people disclosing information they shouldn't, yet still having the public interest defense available to them) and though this is of course problematic, I consider it less problematic than the alternative. If one punishes people who reasonably believed to be blowing the whistle on grave government wrongdoing, the result will likely be overdeterrence: Potential whistleblowers will prefer to err on the side of caution and thus to remain silent. Such a chilling effect risks depriving the public of crucial information concerning government wrongdoing.

A full public interest defense would contain two further conditions, constraining the manner in which a justified disclosure ought to be carried out. I will briefly expound them here, though my main concern is with the public interest condition, for completeness' sake but also because they may help in allaying the concern (discussed in the previous paragraphs) that my approach would result in excessive whistleblowing. Before discussing these two procedural conditions, however, it must first be noted that the public interest condition must be understood as a threshold condition. That is to say, if it is not met, the defense immediately becomes unavailable. By contrast, the two procedural conditions determine whether the defense will function as a full defense or rather as a sentencing mitigation factor.

The ultimum remedium condition states that public disclosures ought to be a measure of last resort. One ought to first exhaust all alternative channels. In practice, this means one ought to first ad- 
dress the wrongdoing internally. In this manner, those in charge have the opportunity to investigate the wrongdoing and sanction those responsible or, alternatively, to explain why, in fact, no wrongdoing has occurred, without involving the public at large. This process can thus also help prevent disclosures of information that either does not demonstrate wrongdoing, or that does demonstrate wrongdoing but the potential benefits of the disclosure of which do not outweigh the potential costs. Such an internal investigation provides, after all, a first test: Is the information authentic? Does it demonstrate wrongdoing? Does disclosure of such wrongdoing outweigh the costs? In this manner, it can help prevent disclosures that, upon reflection, are not in the public interest.

But, if one's complaint is not acted upon or if one reasonably believes the internal procedure to be infeasible (perhaps those responsible for the wrongdoing are able to influence or even block the internal investigation), one can then lodge one's complaints with an independent oversight body. This, too, makes it possible to address the wrongdoing in a confidential manner. If both alternative channels have been exhausted without result, or if the whistleblower reasonably believes that making the disclosure internally or to an independent oversight body will be in vain, or will lead to the destruction of evidence, or to reprisals against herself or a third party, or if the information involved concerns an imminent risk or threat 'to the life, health, and safety of persons, or to the environment', ${ }^{73}$ then the whistleblower may reveal the information to the public.

The minimize harm condition enjoins the whistleblower to take all possible steps to minimize the harm that may ensue from her disclosure. Especially when the information concerns matters of national security, unauthorized disclosures may cause substantial harm to undercover agents in the field, to ongoing military operations, and to national security. In order to mitigate such harm, the whistleblower would be wise to collaborate with established media outlets who can help edit the information so that only the information strictly necessary to reveal the wrongdoing is made public and nothing more. Experienced journalists can, furthermore, help determine the information's authenticity as well as present the

\footnotetext{
${ }^{73}$ Tshwane Principles, Principle 40a, supra note 16.
} 
information in such a manner so that the intended audience will adequately receive and comprehend it. The imposition of this condition is thus another way to prevent undesirable unauthorized disclosures. Together with the ultimum remedium condition and the objective 'reasonable belief test, it should go a long way in preventing unauthorized disclosures that are not in the public interest.

The attentive reader will have noticed that I have not included the 'good faith condition', which several whistleblower protection laws do contain. ${ }^{74}$ The reason for the omission is simple: what matters is the content of the information. So long as the public interest condition has been fulfilled, it is irrelevant that the whistleblower's motives were not entirely immaculate. If disclosure serves the public interest, to be determined by the objective reasonable belief test, it does not matter that the whistleblower also had a private interest in disclosure. The thought is that a disclosure can still be in the public interest, even though it may also be in the private interest of the whistleblower. Disclosing Watergate, for example, was certainly in the public interest, even though personal resentment (over having been passed over for promotion) may also have played a role. So the whistleblower need not be a perfect Kantian agent who acts solely aus Pflicht (from duty) in order to benefit from the public interest defense. We need not require that her motivations be exclusively public-spirited. What we should require, however, is what has already been mentioned above, namely that the whistleblower must have actually held the belief that her disclosure would better serve the public interest than continued secrecy. ${ }^{75}$ The reason why is that such a subjective reasonable belief test renders the public interest defense unavailable to so-called 'unknowing necessity cases'. ${ }^{76} A$ 's case constitutes a case of unknowing necessity if her disclosure is, as a matter of fact, necessary to avoid a greater threat to the public interest, but she acted in ignorance of this information. Imagine, for example, that $A$ randomly discloses classified documents simply so

\footnotetext{
${ }^{74}$ See, e.g., the case law of the European Court of Human Rights: e.g., ECtHR, Guja v. Moldova, $\S$ 77, supra note 14; Heinisch v. Germany, no. 28274/08, $\S \S 82-87$, (ECtHR 2011); Bucur and Toma v. Romania, no. 40238/02, $\S \S 116-118$, (ECtHR 2013).

${ }^{75}$ I thank an anonymous reviewer for Law and Philosophy for pressing me on this point.

${ }^{76}$ For interesting discussions of such cases see, e.g.: Larry Alexander, 'Lesser Evils: A Closer Look at the Paradigmatic Justification', Law and Philosophy 24 (2005): pp. 611-643, pp. 626ff.; Mitchell N. Berman, 'Lesser Evils and Justification: A Less Close Look', Law and Philosophy 24 (2005): pp. 681-709, pp. $702 \mathrm{ff}$.
} 
she can impress her friends with her security clearance. As it happens, the information she discloses actually does more good than harm to the public interest. Still, we would not want the defense to be available to $A$. Our reasons could be both consequentialist (denying her the defense could help prevent her (and possibly others, through deterrence) from engaging in such frivolous disclosures in the future) and retributivist (by denying her the defense, we prevent her from getting away with such dangerous and irresponsible behavior). To sum up, the whistleblower need not have acted in good faith, understood as having immaculate motivations. She must, however, have actually believed that her disclosure would be in the public interest.

Finally, if the whistleblower has met all three of the above conditions - public interest (consisting of both an objective and a subjective reasonable belief test), ultimum remedium, and minimize harm - to the best of her ability, then the only way the government can maintain its position that the unauthorized disclosure is unjustified (and the whistleblower, therefore, ought not to enjoy legal protection against retaliation) is by arguing that, for example, the whistleblower was in no position to adequately assess where the public interest lies (with disclosure or with continued secrecy), because she did not have access to all the relevant information, causing her to overlook a specific and substantial harm to the public interest that outweighs any benefits to the public interest effected by the disclosure.

Before discussing possible objections to the public interest defense for classified public whistleblowing as provided in these pages, let us pause and take stock. The public interest defense is a justification defense. For the defense to be fully available to the whistleblower, her disclosure must meet three conditions: the public interest condition (consisting of both an objective and a subjective reasonable belief test), the ultimum remedium condition, and the minimize harm condition. If the first condition is not met, the defense is unavailable. If the latter two are not met, the defense will likely serve to mitigate the sentence rather than function as a full defense. For the public interest condition to be met, the benefit to the public interest brought about by the disclosure must outweigh the possible harm caused by it (or it must at least have been reasonable for the 
whistleblower to believe that it would). In practice, this requires weighing against each other competing interests we share as members of the public, which I have defined as interests in those conditions necessary for the possibility of pursuing our private interests. In cases of conflicting public interests (privacy and security, for example), the defense requires the judge to determine which of the competing shared interests involved is the more fundamental condition for the possibility of pursuing our private interests. Furthermore, it requires a determination of the extent of the harm done to security, say, or to particularly weighty private interests, and the significance of the benefit to privacy. Perhaps, generally speaking, we might say that security is a more fundamental condition than privacy, but if the detriment caused to the former by the disclosure is relatively small and the benefit to the latter is rather large, disclosure is still in the public interest and thus the defense ought to be available to the whistleblower. Finally, even if it turns out no wrongdoing was involved, or that there was wrongdoing but the harm caused by disclosure in fact outweighs the benefits brought about by it, the defense ought to still be available, provided that it was reasonable for the whistleblower to believe that her disclosure was in the public interest and that she actually held this belief.

\section{OBJECTIONS}

A first possible objection to this public interest defense for whistleblowing (let us call it the epistemic constraints objection) would argue that it demands too much of the potential whistleblower; if she wants her disclosures to be covered by the defense she will need to determine where the public interest lies and, in cases of conflict, which of the shared interests outweighs the other. Furthermore, she will need to make an assessment of the possible harm that could be precipitated by her disclosure and weigh that against the benefit to the public interest. Some might doubt that an average civil servant possesses all the relevant knowledge to make such an assessment. Lower-level civil servants in particular may not have access to all the information necessary to determine whether a secret policy involves grave harm to the public interest and whether disclosure would involve harm to national security, say, or to third parties. David Estlund would argue that in such circumstances the civil servant 
ought to refrain from disclosing the secret policy in question and respect its classified status, because it is the result of an institutional process with significant epistemic value. Our best evidence, he maintains, that a policy is morally acceptable is that it is the product of an institutional process designed to duly look after the question whether it is just. ${ }^{77}$ It follows that a civil servant acts wrongfully, for epistemic reasons, by substituting her own private judgment for the state's decision, which is the result of an institutional process with significant epistemic value. A public interest defense, according to this line of argument, would not be desirable as it would encourage civil servants to take it upon themselves to weigh the public interest in disclosure against the public interest in continued secrecy, whereas this is properly a public task, provided the political and institutional processes are aimed at arriving at the right answer.

There is some merit to this objection, and indeed I have already conceded that the determination of where the public interest lies is not without its difficulties. However, I have also pointed out that there are ways to attenuate this difficulty (e.g., by seeking out (legal) advice, and consulting the relevant case law). Furthermore, there are plenty of cases of relatively straightforward wrongdoing: Watergate, Abu Ghraib, political corruption. In these and similar cases, the fact that the individual civil servant does not possess all the facts is not likely to be an obstacle for adequate moral judgment.

A further reply to this objection is that often a civil servant may feel compelled to blow the whistle precisely because the institutional procedures that are usually abided by, and which, according to Estlund, produce authoritative commands due to their 'effort and tendency to get the right answer, ${ }^{78}$ are set aside or are defective. As an example, consider the executive's decision to wage war without first consulting and obtaining approval from the legislature. In such a case, Estlund's argument would no longer apply as the very procedure which results in authoritative commands has been bypassed. ${ }^{79}$

${ }^{77}$ David Estlund, 'On Following Orders in an Unjust War', The Journal of Political Philosophy 15 (2007): pp. 213-234, p. 222.

${ }^{78}$ Ibid., p. 221.

${ }^{79}$ Indeed, Estlund seems to concede this point and even argues that '[s]oldiers lower down in the chain of command also have a responsibility to ask themselves whether justice is being looked after' (ibid., p. 226), that is, whether the institutional and procedural safeguards are functioning properly.

${ }^{80}$ Sagar, Secrets and Leaks, p. 120, supra note 11. 
The second objection concerns what Rahul Sagar has termed the 'incommensurability of interests' ${ }^{80}$ He argues that there is no firm basis on which we can weigh, for example, the public interest in security (which presumably calls for secrecy, at times) against the public interest in political accountability (which requires transparency). This, too, is a valid point. It is my hope, however, that the civic account of the public interest (defense) expounded in these pages can be a guide in what Sagar describes as the 'messy reality' of interest balancing. ${ }^{81}$ It allows us, first of all, to identify public interests as interests that we share as members of the public in the conditions that make it possible for each of us to develop and strive to realize our own values, objectives, and life plans. Furthermore, it enables us to attach different weights to our various shared interests in accordance with how instrumental the conditions concerned are in facilitating the realization of our private interests. The more fundamental a condition is for the possibility of pursuing our private interests, the greater the weight that ought to be attached to it. In deciding, finally, whether disclosure or continued secrecy best serves the public interest, we ought also to consider the degree of harm involved with disclosure and the magnitude of the benefit.

Now, Sagar is of course right to point out that all this may be difficult to do for a judge who has to decide whether a particular unauthorized disclosure was in the public interest. But I am more optimistic regarding the courts' ability to reach such a decision. They are generally quite able to deal with complex and controversial issues. In hate speech cases, for example, the judge must also undertake a complicated balancing test: She will need to weigh the value of the individual's right to freedom of expression against the harm his hateful speech is believed to cause to an already marginalized ethnic or religious minority. The harm involved is often not very concrete or specific. Yet, the court will have to attach a particular weight to it and consider whether the prevention of such harm outweighs the value of free speech. Similarly, Heidi Kitrosser won-

\footnotetext{
${ }^{81}$ Ibid.

${ }^{82}$ Heidi Kitrosser, 'Classified Information Leaks and Free Speech', University of Illinois Law Review 3 (2008): pp. 881-932, p. 913: 'In such [complex] cases, parties bring the courts up to speed through evidence and briefings. Among the judiciary's strengths in this respect are its familiarity with studying complex factual records and accompanying briefings, its ability to demand additional information and expert assistance from the parties, and its ability to call in court-appointed experts for additional assistance'.
} 
ders whether whistleblowing cases are really more complex than the intricate environmental, scientific, and financial cases, which courts are deemed capable of dealing with. ${ }^{82}$

Despite the courts' general ability to successfully deal with complex cases, however, their application of the public interest in whistleblowing cases thus far has been criticized as ad hoc and idiosyncratic (as pointed out already towards the end of the introduction). Yet, the problem was not so much the courts' judgment or their ability to study complex documents, but rather that they had to exercise their otherwise considerable capabilities in the dark, as it were, with little to no guidelines to assist them. It is precisely this lack that the civic account of the public interest (defense) aims to remedy. The guidance provided by it, combined with the courts' substantial abilities, should be sufficient to adequately deal with public interest defenses of whistleblowing, or at the very least to improve the courts' disappointing track record so far. The complexity of weighing interests against each other, therefore, does not warrant the abandonment of the public interest defense as expounded in this article.

The third objection - the reasonable disagreement objection - does not so much argue that the whistleblower is in no position to judge where the public interest lies due to epistemic constraints (as with the first objection), but rather that, even if she were in possession of all the relevant facts, there could still very well be reasonable disagreement over how the relevant facts ought to be judged. Informed people may still disagree over whether a given classified policy constitutes a threat to the public interest and thus whether its disclosure serves the public interest or not. Creating a defense, the key term of which, so this argument goes, is necessarily open to interpretation, will only generate more disputes than it settles. Furthermore, the ambiguity of the central concept will make it all the easier for a government to dismiss a whistleblower's appeal to the public interest as 'just another interpretation'. In short, the argument goes, a public interest defense will not resolve anything, due to the indeterminate nature of the public interest.

Once again, my first reply would be that there are plenty of cases of uncontroversially wrongful government conduct (e.g., abuse of 
power, political corruption, Abu Ghraib, Watergate). Such cases are not susceptible to this counterargument.

Furthermore, reasonable disagreement does not necessarily present an argument against disclosure if the wrongdoing in question is procedural rather than (exclusively) substantive. For example, the problem with the government's implementation of a secret largescale domestic surveillance program is not only that some might deem it unjust, but rather that such a policy is a matter of public concern (as it impacts fundamental rights), about which, accordingly, the public ought to be informed. If what matters is that citizens are able to form an opinion concerning the policy in question through public debate, ${ }^{83}$ which is made impossible by the policy's secret nature, then reasonable disagreement concerning the policy's desirability is not an argument against disclosure.

Finally, though there can be no disagreement over which interests are public interests (according to the civic account defended here, public interests are interests in those conditions that make it possible for each of us to develop and strive to realize our own values, objectives, and life plans), it is possible for there to be disagreement over the weight we ought to attach to our various shared interests. But is this a problem for the functioning of the defense? I believe it is not. Recall that the whistleblower who wishes to benefit from the defense need not show that her assessment of what better serves the public interest (disclosure or continued secrecy) is ultimately the correct one. Instead, she needs to demonstrate that she had a reasonable belief that her disclosure revealed a threat to the public interest and that the benefits of disclosure would outweigh the possible associated harms to the public interest. (Recall, too, that our reason for this approach was to avoid a chilling effect.) It follows that reasonable disagreement (between the whistleblower and the government) over the weight to be assigned to competing public interests cannot be a ground for denying the whistleblower the defense. Indeed, typically this is not the approach taken by governments. Often they will decide to prosecute a whistleblower not

\footnotetext{
${ }^{83}$ Of course, the government need not (and at times ought not to) publicize each and every detail concerning the secret policy, as that might very well undermine the policy's functioning, endanger national security, or have other undesirable effects. Often, however, the government can disclose the general contours of the policy, which can safely be the subject of public debate. Dennis Thompson refers to this as 'partial secrecy' (Dennis F. Thompson, 'Democratic Secrecy', Political Science Quarterly 114 (1999): pp. 181-193).
} 
because she incorrectly attached more weight to privacy than to security, for example, but rather because her disclosures allegedly damaged national security more than she had (or even could have) foreseen. In other words, the problem is not so much that the whistleblower attached too little weight to the shared interest of security, say, but rather that she made an incorrect assessment of the harm that might ensue from her disclosure. She may thus fail to meet the second procedural condition (after all, minimizing harm presupposes a sincere effort to adequately assess the possible harm). In this case, the defense could at most function only as a sentence mitigating factor. However, she might also fail to meet the first condition (the public interest condition). This condition requires weighing the benefits of disclosure against its possible harmful consequences. If the whistleblower did not make an adequate assessment of the potential harm that might ensue, or was perhaps even negligent in making the assessment, then she fails the public interest condition as well, in which case the defense is not available to her at all. But the burden of proof then lies on the government to demonstrate that the unauthorized disclosure has indeed caused far more harm to the public interest than foreseen by the whistleblower, and that this harm outweighs the benefits of disclosure.

In sum, typically the argument the government would make is not that we ought to attach a greater weight to security than to privacy or political accountability, say, but rather that the whistleblower has made an incorrect assessment (perhaps negligently so) of the harm that might ensue from her disclosure. It is thus not primarily a matter of reasonable disagreement over values, but rather of incorrect assessment of harm. The reasonable disagreement objection, therefore, misses the mark.

\section{CONCLUSION}

As announced at the outset, this paper set out to (1) clarify the concept of the 'public interest', and (2) to determine whether a public interest defense is feasible and desirable. Regarding the first point, Section III presented the civic account of the public interest, which expands upon Barry's account of the public interest. The interests that we share in our role as members of the public, i.e. public interests, are interests in the conditions that make it possible 
for each of us to develop and strive to realize our own values, objectives, and life plans. In other words, the interests we share as members of the political community are interests in conditions that need to be in place if all members are to be able to pursue their own interests. Examples of such conditions are the rule of law, the separation of powers, human rights, legal certainty, and political accountability.

Regarding the feasibility and desirability of the public interest defense for whistleblowers presented in Section IV, the previous section has shown that it is not without its difficulties. However, I also hope that my replies to the objections discussed there as well as my exposition of the public interest and the public interest defense in Sections III and IV respectively, have demonstrated that such a defense certainly is workable and feasible. The civic account of the public interest provides sufficient guidance for judges to undertake the necessary balancing test. This ought to do away with the excesses of judicial discretion, which at present leads to legal uncertainty, which, in turn, may lead potential whistleblowers to refrain from disclosing government wrongdoing for fear of retaliation. The defense is, therefore, indispensable (and thus desirable). Without it, we risk depriving ourselves of what has become the most important source for finding out about government wrongdoing. In sum, the public interest defense, despite its difficulties (which I have shown to be generally surmountable), is feasible as well as necessary. Moreover, it is our only option to provide protection to justified cases of classified public whistleblowing, given the untenability of a rightsbased defense.

\section{OPEN ACCESS}

This article is distributed under the terms of the Creative Commons Attribution 4.0 International License (http:// creativecommons.org/licenses/ by $/ 4.0 /$ ), which permits unrestricted use, distribution, and reproduction in any medium, provided you give appropriate credit to the original author(s) and the source, provide a link to the Creative Commons license, and indicate if changes were made. 
Utrecht, The Netherlands

E-mail:e.r.boot@uu.nl

Publisher's Note Springer Nature remains neutral with regard to jurisdictional claims in published maps and institutional affiliations. 